\title{
Absorption Policies For South-South Migration
}

George Andreopoulos, City University of New York Giuliana Campanelli, Andreopoulos, (Email: andreopoulosg@wpunj.edu), William Paterson University Alexandros Panayides, William Paterson University

\begin{abstract}
The South-South migration has increased enormously over the past forty years and its effects on the level of economic development and security for the host and neighboring states can be extremely problematic. Paradoxically the vast part of the literature on international migration still focuses on the South-North migration, leaving aside the South-South one and its implications. The scope of this paper is to analyze the effects of South-South migration on a country at low level of development and explore policies geared towards the absorption/integration of migrant workers.
\end{abstract}

\section{INTRODUCTION}

$\mathscr{I}$ migration took place within the developing world. Paradoxically, this South-South migration has almost been ignored by the literature as well as the media, which focus on the South-North international migration.

The scope of this paper is to discuss the effects of international migration on the receiving country's economic development and to assess policies to absorb/integrate migrant workers. In particular, we extent some of the results of our previous research on the effects of international migration on a country at a very low level of development (Andreopoulos et. al, 2005). For this purpose, we recall the Lewis two-stage model which examines the dualistic structure of a country's economy at different levels of development. We believe that the Lewis model, despite its limitations ${ }^{1}$, continues to be the most appropriate in explaining the functioning of the labor market and economic growth in developing countries. The paper is organized as follows. Section two summarizes the main characteristics of South-South migration. Section three recalls the Lewis model and introduces international migration. Section four expands our previous research by exploring policies geared towards the absorption of migrant workers. Finally, section five provides concluding remarks.

\section{CHARACTERISTICS OF SOUTH-SOUTH MIGRATION}

The South-South migration is quite different from the South-North migration. First, the South-South migration is more complex than the South-North migration. It can also be explained by economic disparities (for example the migration towards the Middle East oil producers, the so-called Asian tigers and South Africa), but it can also be due to environmental degradation/resource scarcity (in addition to many African countries, one interesting example is that of Bangladesh) and political and social factors. In particular, we refer to movements of refugees and internally displaced persons.

Second, in the South-South migration the involuntary component is essential in the explanation of migration. In the case of South-North migration the voluntary component is crucial especially for the"brain drain." As an example of the involuntary component one can recall the end of the cold war and the consequent new range of

\footnotetext{
${ }^{1}$ On this issue see Todaro and Smith (2003).
} 
regional conflicts such as those in the ex-communist countries, the Middle East and Africa (as exemplified by the cases of Former Yugoslavia, Chechnya, Kuwait, Congo, Liberia, Sierra Leone, Somalia, Sudan, Rwanda, and Uganda). These conflicts have produced massive flows of migrants and political refugees towards not only developed but also developing countries.

The total number of refugee and internally displaced persons has increased enormously over the last twenty years and reached 40 million in 2002. Approximately four fifth of all refugees found asylum in Africa or Asia, with the rest migrating to Europe (15\%) the Americas (4\%) and Oceania (0.4\%). Among the refugees, Palestinians and Afghans are the largest group and most of them went to the Near East (Jordan, Lebanon, Syria, Gaza or the West Bank) and in Iran. According to the Global IDP Project, the majority of internally displaced people live in Africa, particularly in Sudan where, for more than twenty years, a civil raged in the southern part of the country.

\section{THE EFFECT OF SOUTH- SOUTH MIGRATION ON A COUNTRY AT LOW LEVEL OF DEVELOPMENT}

Recalling our previous research (Andreopoulos et. al, 2005) we illustrate the main characteristics of the Lewis model (1954). Lewis identifies a crucial distinguishing feature of developing countries - a dualistic structure of their economy. The two major sectors of this economy are the traditional (subsistence) one and the modern (industrial) one. The traditional sector includes not only people involved in agriculture but also petty traders, servants, women in household, and other groups without any formal employment. At the very early stage of development (Phase 1), there is an enormous surplus of labor in the traditional sector, i.e., the labor force can be taken out of this sector without any loss of output because the marginal labor productivity equals zero. The modern (industrial) sector is controlled by individuals who possess capital and hire the services of labor. This sector has a higher level of productivity and output expansion than the traditional sector; the speed of the expansion depends on industrial investment and capital accumulation. To these two different sectors correspond two different levels of wages. At a very early stage of development, Phase 1, both wages are exogenously given at the subsistence level (institutional wages). The only difference is that this subsistence wage is higher in the industrial sector mainly due to higher rents, transport cost and a premium for the psychological cost of transferring from the subsistence to the capitalist sector. Lewis claims that this gap is thirty percent; however he does not provide any empirical justification for this figure.

The supply of labor in the modern sector is horizontal at the early stage of development indicating an infinite number of workers willing to work at the existing wage (Phase 1), while at higher levels of development (Phase 2 and 3) becomes upward sloping as in the neoclassical model (see figure 1). (Following the Ranis and Fei (1961) notation, $\frac{w}{p}$ is the real wage, $L_{L}$ is the amount of labor in the industrial/modern sector, $S_{I}$ is the supply of labor in the industrial/modern sector, $L_{A}$ is the amount of labor in the agricultural/traditional sector, $\mathrm{S}_{\mathrm{A}}$ is the supply of labor in the agricultural/traditional sector, and $L_{T}$ is the total amount of labor in the economy). The same effect, but with a time lag, manifests itself in the traditional sector (see figure 2). 

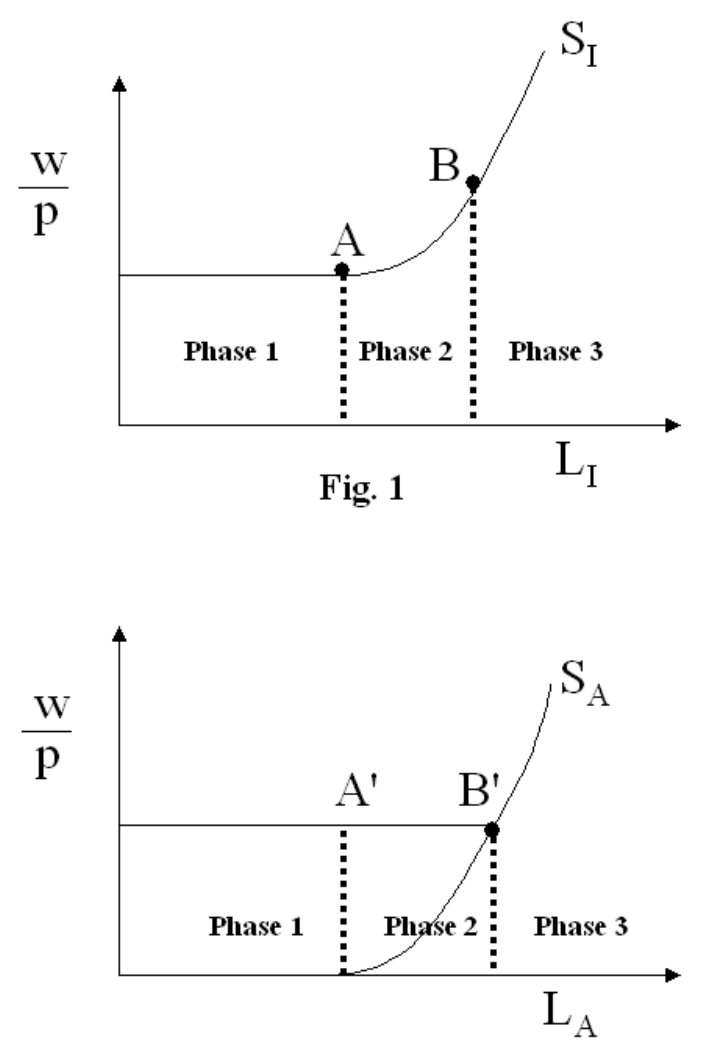

Fig. 2

The basic idea for the upward sloping supply curve of the modern sector is that, as this sector absorbs more and more workers from the traditional sector, the labor surplus decreases but also its output is reduced with a consequent increase in the price of food. This is what Lewis defines as the "worsening of the terms of trade" for the industrial sector, which results from a relative shortage of agricultural commodities. The cost of living starts rising and the modern sector requires a higher level of wages to attract workers. This is considered as the second stage of development. A third stage of development is when the supply of labor for the traditional sector also becomes upward sloping. This happens when there is an exhaustion of the labor surplus in the traditional sector and the marginal productivity of labor in this sector exceeds the institutional real wage. At the end of this process the traditional sector can be said to have become commercialized, Ranis and Fei (1961). The equilibrium between the supply and demand curves from now onwards determines the level of real wages and the quantity of employment like in the neoclassical model in both sectors.

According to Lewis the process of development is accompanied by an increase in the surplus of labor due to the following three reasons. First, an increase in the participation rate of women, second an increase in population and third an increase in efficiency due to technical progress. We can now introduce a fourth reason for the increase in the surplus of labor: international migration.

In our earlier research (Andreopoulos et. al, 2005), we studied the effects of South-South migration for a country at the early stage of development (Phase 1). In what follows, we extend our previous analysis by considering the policies to integrate migrant workers. 
Let's assume that all the workers are of unskilled type, ${ }^{2}$ the receiving country is at early stage of development (Phase 1) and most of the migrants - mainly of involuntary type - go to the traditional sector. The surplus of labor increases and, ceteris paribus, prolongs the horizontal segment of the supply curve in the traditional sector. The indirect effect will be a delay in the upward shift of the supply curve in the modern sector, as illustrated in figure 3.

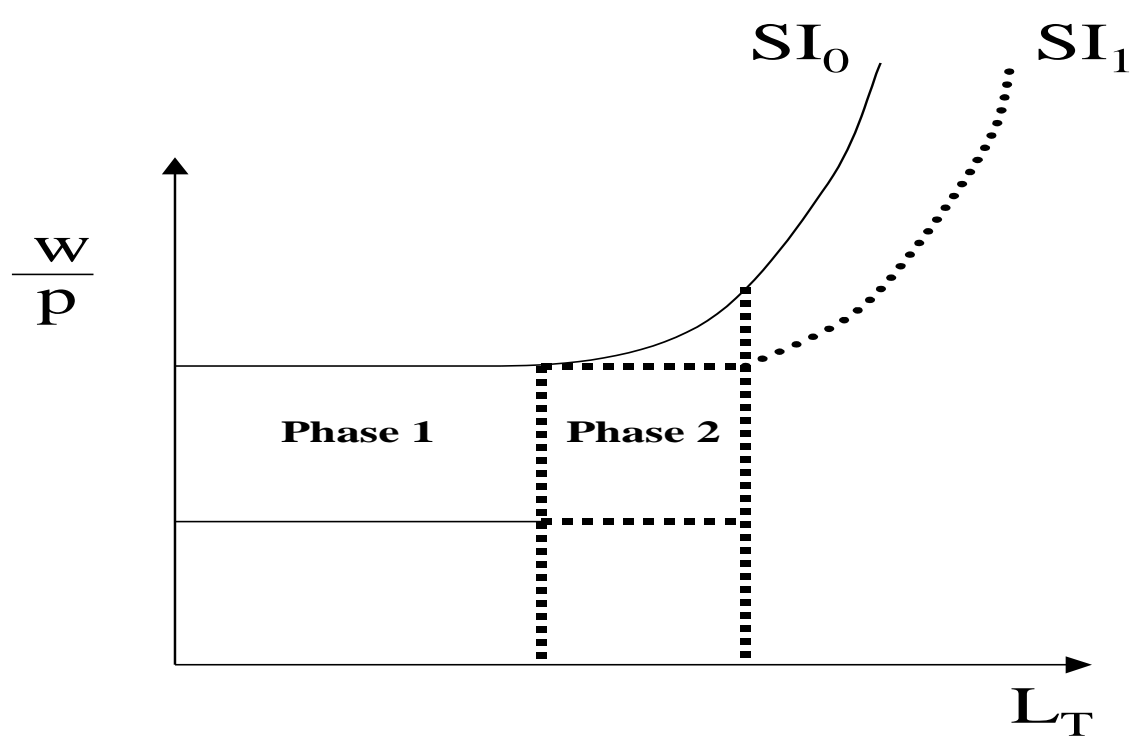

Fig. 3

As a result of the delay in the upward shift of the modern sector's supply curve, the wage determination continues to be unaffected by demand and supply forces in both sectors.

\section{ABSORPTION POLICIES}

According to Lewis there is a way to avoid delays in the upper shift of the modern sector's supply curve: a faster growth of the industrial sector. In this case the industrial sector has to absorb more and more labor from the traditional sector, including the migrants.

The amount of the supply shift depends on government policies. In this case, we assume that the government has no interest to increase the already existing enormous surplus of labor unless it does for humanitarian reasons such as helping refugees or internally displaced persons.

However, if we take the case on many African countries, and in particular we look at the refugee component, it is clear the humanitarian considerations are relevant, but the effects of migration and the consequent absorption policy for the host state merit further attention.

As the evidence shows, the first problem with refugees is to ensure physical safety and the inability and/or reluctance of host governments to integrate these populations pose security risks. If a government pursues a policy of

\footnotetext{
${ }^{2}$ It is worth adding that, on the contrary, the South-North migration might includes a vast amount of highly skilled workers from the developing countries, the so-called "brain drain". According to recent ILO estimates, the brain drain is responsible for the loss of 10 to 30 per cent of skilled manpower in developing countries. There are substantial variations in these numbers among different regions. For example, in the case of Africa, ILO studies indicate that up to 75 per cent of persons emigrating to OECD countries have completed tertiary level education, or equivalent technical training; the corresponding figure from Latin America is around 47 per cent (IMP/UNFPA, 2004).
} 
keeping refugees and IDPs in camps, it must ensure that they remain civilian entities. This means that the camps must be free from armed elements and cannot be used as terrain for military activities (Jacobsen, 2001). However, ensuring the civilian nature of settlements is a difficult task, as the case of the camps in Goma, Eastern Zaire (now Democratic Republic of Congo), in Tanzania, in West Timor, in Zambia, and in the Parrot's Beak area of Guinea demonstrate, among others. Refugee camps were used by the Rwandan genocidaires, for example, as places for regroupment, reassertion of their authority vis-à-vis the displaced population, and as launching pads for cross border attacks. In a climate of increasing camp insecurity, humanitarian assistance was diverted and ended up benefiting those responsible for the humanitarian crisis, rather than alleviating the suffering of the victims (Medecins Sans Frontieres/Doctors Without Borders, 1995). Given the dynamics involved in these settlements, as well as their spill-over effects, a concerted and internationally assisted effort towards absorption/integration could provide both economic and security benefits.

Once physical safety is guaranteed the next step is integration.

By integration we mean the ability of refugees to leave the camps and participate in the economic and communal life of the host country. Full legal rights and full political participation can be too ambitious in the short/intermediate term. A high level of refugees' integration is characterized by the following indicators:

- $\quad$ Refugees are dispersed among the local population

- $\quad$ Refugees and their children are able to utilize local services such as health facilities and school

- Refugees participate to the local economy.

There is not a universal policy to promote integration because, as the evidence suggests, its success depends on the following seven factors:

$\begin{array}{ll}\text { - } & \text { Political/Security factors } \\ \text { - } & \text { Legal factors } \\ \text { - } & \text { Gocio-economic factors } \\ \text { - } & \text { Temporal factors } \\ \text { - } & \text { The size of the refugee population } \\ & \text { Refugee actions }\end{array}$

In the case of countries at low level of development one can assume that economic factors play a crucial role in particular because refugees do not constitute a complementary labor force, but a threat to domestic employment. In addition, they are quite poor; thus they do not represent a boost to demand but a drain on resources.

The empirical evidence on Kenya appears very interesting in this respect. Kenya shows a wide range of integration patterns among its population. In particular, Ethiopians integrated very well, while Sudanese and many Somalis are still in camps. This can mainly be explained by economic considerations. Many Ethiopian refugees come from urban areas and are relatively well off. On the contrary the Sudanese, who have the fewest resources of the three groups, have the lowest rates of absorption (Banki, 2004). While a high percentage of Ethiopian refugees are urban and well educated, employment opportunities of thousands of poor refugees from Somalia and Sudan are virtually nil. Thus, in the case of Kenya, factors related to wealth/skills, rather than political, or security factors take precedence in the integration process.

This also means that the size of the refugees' population is crucial because as the poor component of the refugees' population grows relative to the size of the host country population, resources are drained and the host population can grow resentful. As a result, governments can modify their integration policies, or even reverse them like in the case of Ghana (with the Liberian refugees). In addition, the case of Kenya shows that to improve refugee integration, empowerment opportunities constitute a vital first step. These would include recognition under the law, skill training, and micro credit projects which represent powerful tools to rebuild their lives, irrespective of the final destination (whether it is local integration, repatriation to the home country, or resettlements to third countries). 
Needless to say, many actors should be involved in this process of integration: host governments, donor governments, international/regional organizations, the business community and finally the refugees themselves.

\section{CONCLUSION}

The scope of this paper has been to analyze the effects of South-South migration on a country at low level of development and to suggest policies to integrate/absorb migrant workers. For this purpose, we used the Lewis model in which the level of development is crucial to our understanding of the functioning of the labor market, while we added migration as an additional source of labor surplus, as well as the role of the government in controlling migration.

The main results are as follows: First, if migrant workers (particularly of involuntary type) move to a country at a very early stage of development they increase the surplus of labor in the traditional sector and by doing so they indirectly delay the process of development of the modern sector. Second, wages continue to remain constant at the institutional level in both sectors. Third, South-South migration can also pose security problems to the host and neighboring states because the camps can be used by armed elements as a terrain for military activities. Consequently it is necessary to separate the armed elements from the civilian population. Fourth, absorption/integration policies which provide empowerment opportunities can have potentially positive effects not only on development, but also on host country and regional security.

\section{REFERENCES}

1. Andreopoulos, G., Campanelli Andreopoulos, G., Antoniou, E., and Panayides, A. (2005). The Effects of South-South Migration on Economic Development and Its Security Implications. International Business and Economics Research Journal, 7 (4), 17-22.

2. Banki, S. (2004). Refugee integration in the intermediate term: a study of Nepal, Pakistan and Kenya. The UN Refugee Agency. Working paper no. 108

3. Division for Social Policy and Development, Department of Economic and Social Affairs, United Nations (2004), Social Dimensions of International Migration, UN/POP/MIG/2004/8.

4. Ellerman, D. (2003), Policy Research on Migration and Development. World Bank Policy Research Working Paper no. 3117.

5. Gould, W. (1994), Population movements and the changing world order: an introduction, in W. Gould and A. Findlay (eds.), Population Migration and the Changing World Order. New York: John Wiley \& Sons.

6. International Migration Policy Programme and United Nations Population Fund (2004), Meeting the Challenges of Migration: Progress Since the International Conference on Population and Development

7. Lewis, A. W. (1954), Development with Unlimited Supply of Labor. The Manchester School 22: 139-92.

8. Ranis, G., J. H. Fei. (1961), A Theory of Economic Development. American Economic Review. 51: 533-565.

9. Ranis, G. (1997), The Micro-Economics of Surplus Labor. Economic Growth Center. Yale University. Discussion Paper \#772.

10. Refugee Protection in Africa: How to Ensure Security and Development for Refugees and Hosts. (2002). Policy Bulletin, The Stanley Foundation.

11. Todaro and Smith (2003), Economic Development. Addison Wesley, $8^{\text {th }}$ edition. 